\title{
Pheno-morphological traits of Canola as influenced by nitrogen and green manuring crops (species, parts and age) under semiarid condition
}

Khalid Ali ${ }^{1}$, Amanullah Jan ${ }^{2}$, Amanullah ${ }^{2 *}$ and M. Jamal Khan ${ }^{3}$

1. Agriculture Research Institute (ARI) Tarnab, Peshawar

2. Department of Agronomy, The University of Agriculture, Peshawar

3. Department of Soil and Environmental Sciences, The University of Agriculture, Peshawar

*Corresponding author's email: amanullah@aup.edu.pk

Citation

Khalid Ali, Amanullah Jan, Amanullah, and M. Jamal Khan. Pheno-Morphological Traits of Canola as Influenced by Nitrogen and Green Manuring Crops (Species, Parts and Age) under Semiarid Condition. Pure and Applied Biology. Vol. 4, Issue 3, 2015, pp 362-374. http://dx.doi.org/10.19045/bspab.2015.43012

\begin{tabular}{lll}
\hline \hline Received: 02/07/2015 & Revised: 22/08/2015 & Accepted: 28/08/2015 \\
\hline
\end{tabular}

\section{Abstract}

Field experiments were conducted at the Agriculture Research Institute Tarnab, Peshawar to study the impact of two green manuring crop species (guar and millet), their age (40, 70 and 100 days after sowing, DAS) and parts (whole plants and stubbles) under varying nitrogen levels $(0$, 75 and $100 \mathrm{~kg} \mathrm{ha}^{-1}$ ) on pheno-morphological traits of canola (Brassica napus L. cv. Bulbul-98). Findings of the experiments revealed that guar as preceding green manuring crop had significantly increased plant height (8\%), leaf area (18\%) and biological yield (12\%). Incorporation of whole plant green manuring had increased leaf area (3\%) and biological yield (4\%) along with delayed maturity of canola crop. Green manuring age had significantly affected leaf area plant $^{-1}$ and biological yield. Leaf area increased when the age of green manuring increased from 40 DAS to 70 DAS; however, it decreased when green manuring was done at the plant age of 100 DAS. Dwarf plants and decrease in BY with the age of incorporation (100 DAS) were observed. Nitrogen application had significantly affected all the parameters except emergence $\mathrm{m}^{-2}$. Increasing $\mathrm{N}$ level from 0 to $100 \mathrm{~kg} \mathrm{ha}^{-1}$ had enhanced LA and BY. Years had significantly influenced all parameters except emergence $\mathrm{m}^{-2}$ and leaf area plant ${ }^{-1}$. In the second year of the experiment, delayed maturity, taller plants and higher biological yield was observed than the first year. It was concluded from this study that incorporation of whole plants of guar as a green manuring crop at either 40 or 70 DAS along with $100 \mathrm{~kg} \mathrm{~N} \mathrm{ha}^{-1}$ resulted improved pheno-morphological traits of canola under semiarid condition.

Keywords: Canola, Green manuring, Nitrogen, Incorporation, Phenology, Morphology.

\section{Introduction}

Rapeseed (Brassica napus L.) is an important oil seed crop throughout the world

Published by Bolan Society for Pure and Applied Biology which ranked third among the oil seed crops after soybean and palm in production of vegetable oil [1]. It is widely grown in 
winter season in irrigated and rain fed areas of Pakistan. Winter oil seed rape has become a plant of major agro-economic importance, with a yield of 62.2 million tons [2]. The presence of high amounts of erucic acid and glucosinolates in rape seed oil is considered toxic for human and animal health, in addition to its bitter taste, has imposed serious health concerns. Safe limits for these compounds have been described as less than $2 \%$ erucic acid in oil and less than $30 \mu$ mole $\mathrm{g}^{-1}$ of glucosinolates in oil free meal [3]. The newly introduced "double zero" canola varieties have low erucic acid and glucosinolates amounts, made canola oil more popular among the consumers in Pakistan [4]. Pakistan is suffering from acute deficiency in edible due to multiple factors. Pakistan major reliance is on the import of edible oil spending more than 2.5 billion US\$ for bridging up the gap between edible oil demand and the domestic production. The total edible oil requirements of the country in 201213 were around 3.069 million tones with domestic production of only 0.567 million tones $(18 \%)$ while the rest of 2.52 million tons $(82 \%)$ of demand is imported [5]. Pakistan yield of canola is $830 \mathrm{~kg} \mathrm{ha}^{-1}$ [6], which is very low as compared to other agriculturally advanced countries of the world like Australia and Canada where average yield ranges from $2000-3000 \mathrm{~kg} \mathrm{ha}^{-1}$ [7]. Nutrient deficiency is one of the major limiting factors causing lower productivity in Pakistan [8]. Nitrogen deficiency is one of the major yield limiting factors [9]. Nitrogen fertilization plays an important role in improving soil fertility and increasing crop productivity [10]. Nitrogen is an integral component of amino acids, proteins, nucleotides, chlorophyll, chromosomes, genes and is also a constituent of all the enzymes. This wide range of different nitrogen containing plant compounds explains the role of nitrogen in plant growth [11]. Compared to cereals, winter oilseed rape requires a higher amount of nutrients and available nitrogen which is worth to be considered in relation to its role in affecting its quality and quantity. Optimum level of nitrogen application can significantly increase production per unit area. Grain quality is directly related with $\mathrm{N}$ fertilization, as little but frequent increase has been observed in grain protein content by $\mathrm{N}$ fertilization [12]. The increase in yield and yield components of canola with the increasing $\mathrm{N}$ rates has also been reported by $[4,13]$ and many other researchers. Green Manuring is a useful mean of sustaining organic matter in the soil and thereby enhances the biological activity, improve soil physical properties and increase nutrient availability. Green manuring is the reliable option for sustainable cultivation. Green manuring alone or in combination with nitrogen fertilizer have positive effects on plant growth and production as well as on soil physiochemical properties [14]. The increased uptake of nitrogen by plants when residues were incorporated was also reported by [15]. Organic matter build up through green manuring has declined over the years as legumes have been virtually eliminated from the cropping systems, which led to serious deterioration of soil fertility. Despite of the great potential of legumes and their significant $\mathrm{N}$ contribution towards improving soil fertility, the adoption of legumes is poor due to wide range of physical and socio-economic conditions [16]. Cultivation of legumes for seed, fodder or green manure has not only helped in improving soil fertility through nutrient recycling, has positively influenced the structure and functioning of the agro ecosystem. Several workers have shown that crop yield and product quality are usually improved when legumes are grown as a preceding crop [17]. Legume residues 
retention improves the $\mathrm{N}$ economy of the cropping system and enhances the crop productivity through the additional $\mathrm{N}$ and many other potential benefits [18]. Combined applications of inorganic $\mathrm{N}$ and crop residue as organic source can be an efficient sustainable practice but choice of appropriate $\mathrm{N}$ application rate is evenly significant [19]. This study tried to examine improvement in phenological and morphological traits of canola. Keeping in view the importance of nitrogen and green manuring, the present experiment was designed with the following objectives.

1. To determine the best crop specie as a green manuring for enhancing Phenomorphological traits of canola.

2. To determine the optimum age of the crop for green manuring.

3. To determine the best $\mathrm{N}$ level for higher yield of canola.

4. To study the relationship between crop species, green manuring, its age at green manuring and $\mathrm{N}$ level on the performance of canola.

\section{Materials and Methods Experimental Site}

Field experiments were conducted at Agricultural Research Institute Tarnab, Peshawar, Pakistan. The institute is situated at a distance of $16 \mathrm{~km}$ to the east from Peshawar city a capital of Khyber Pakhtunkhwa province at $33^{\circ} \mathrm{N}$ latitude, $71^{\circ}$ E longitude and an elevation of 360 meters above the sea level. Temperature and rainfall during the experimental years have been shown in Fig.1 and 2. Mean monthly minimum temperature ranged from $1.0^{\circ} \mathrm{C}$ in January to $14.5^{\circ} \mathrm{C}$ in October and maximum temperature ranged from $17.2^{\circ} \mathrm{C}$ in January to $31.6^{\circ} \mathrm{C}$ in October during the year 2011-12. While mean monthly minimum temperature ranged from $1.0^{\circ} \mathrm{C}$ to $13.8^{\circ} \mathrm{C}$ and maximum temperature ranged from $17.7^{\circ} \mathrm{C}$ to $30.5^{\circ} \mathrm{C}$ in $2012-13$. Total rainfall recorded during the experimental years was $184.3 \mathrm{~mm}$ in 2011-12 and 75.26 $\mathrm{mm}$ in the year 2012-13. The rainfall was much higher in 2011-12 than the 10 years average rainfall $(64.49 \mathrm{~mm})$ of the project area.

\section{Experiment Detail}

The experiment titled " Phenomorphological traits of canola as influenced by green manuring, green manuring crops and age at green manuring under varying levels of nitrogen" was conducted at Agriculture Research Institute Tarnab, Peshawar. The experiment was conducted for a period of two years i.e. 2011-12 and 2012-13. Seed of high yielding, improved canola cultivar "Bulbul-98" was obtained from ARI, Tarnab, Peshawar.

\section{Experimental Procedure}

In summer 2011, two crops i.e. millet and guar were sown with normal cultural practices. These crops were harvested at 40 , 70 and 100 days after sowing. The above ground biomass thus produced was chopped, weighted and either removed or incorporated (known quantity) in the same plots. In case of removal of above ground biomass only the stubbles and roots were incorporated. Keeping the same plot demarcations, in winter season, 2011 canola variety Bulbul-98 was sown on the already established plots. The same experiment was repeated for the second year in 2012. A uniform seed of canola $\left(5 \mathrm{~kg} \mathrm{ha}^{-1}\right)$ was sown in all the plots through hand hoe. In each plot there were 8 rows $5 \mathrm{~m}$ long and $50 \mathrm{~cm}$ apart with a plot size of $4 \mathrm{~m} \times 5 \mathrm{~m}$. Nitrogen was applied at the rate of 0,75 and $100 \mathrm{~kg}$ ha-1 in the form of urea. A basic dose of phosphorus and potash fertilizer at the rate of $60-60 \mathrm{~kg} \mathrm{ha}^{-1}$ was applied prior to sowing with seed bed preparation. The experiment was laid out in Randomized Complete Block Design (RCBD) with split plot arrangement. A combination of crop age at green 
manuring and crop species were allocated to main plots while combination of green manuring and nitrogen were applied to sub plots. In order to obtain optimum plant population thinning was carried out at 30 days after sowing. Weeds were controlled manually. Irrigation was applied when needed. The crop was harvested in the month of April in both years.

\section{Procedure for data recording}

Emergence $\mathrm{m}^{-2}$ was recorded by counting the number of plants in one meter long row at three different places in each sub plot and the counts were then converted in to number of plants per $\mathrm{m} 2$. Leaf area $\left(\mathrm{cm}^{2}\right)$ was measured with the help of a leaf area meter (Licor Model 3000A, USA). Leaf area of ten leaves plant-1 was measured at start of flowering as Brassica napus attain maximum leaf area at that stage [3]. Days to maturity were calculated by counting the number of days from the date of sowing to the date when the color of the pods turns from green to yellow in each sub plot. Plant height $(\mathrm{cm})$ data was recorded by measuring the height of ten randomly selected plants in each sub plot at physiological maturity and then their average was calculated. For total biomass yield, four central rows in each sub plot were harvested, dried and weighted and was converted as $\mathrm{kg} \mathrm{ha}^{-1}$. The data recorded were analyzed statistically combined over years using analysis of variance techniques appropriate for randomized complete block design with split plot arrangement. Main and interaction effects were compared at $\mathrm{P}<0.05$ level of probability using LSD test [20]. During both the growing seasons of the experiment temperature (Maximum and minimum) remains relatively similar. Maximum temperature of $30 \mathrm{C} 0$ at sowing (October) as well as harvesting (April) of the canola crop was recorded. Second year of the experiment (2012-13) has approximately $59 \%$ less rainfall however the rainfall was fairly was distributed as compared to $1^{\text {st }}$ year $(2011-12)$ where rainfall was concentrated only to January and April. As temperature remains identical during crop season and difference in rainfall was compensated with irrigation as per the demand of the crop, any difference in crop response could be related to the other factors of crop production imposed during the experiment.

Table 1. Average air temperature and rainfall at ARI, Tarnab, Peshawar during the crop growing season 2011-12 and 2012-13

\begin{tabular}{|l|c|c|c|c|c|}
\hline Month & $\begin{array}{c}\text { Min T } \\
\left(\mathrm{C}^{\mathbf{o}}\right)\end{array}$ & $\begin{array}{c}\text { Max T } \\
\left(\mathrm{C}^{\mathrm{o}}\right)\end{array}$ & $\begin{array}{c}\text { Average T } \\
\left(\mathrm{C}^{\mathbf{o}}\right)\end{array}$ & $\begin{array}{c}\text { Total Rainfall } \\
(\mathrm{mm})\end{array}$ & $\begin{array}{c}\text { Ten years average } \\
\text { rainfall }(\mathrm{mm})^{*}\end{array}$ \\
\hline October & $14.5(13.8)$ & $31.6(30.5)$ & $23.1(22.2)$ & $26.10(10.15)$ & 4.58 \\
\hline November & $09.2(6.76)$ & $26.7(25.0)$ & $17.0(15.88)$ & $15.80(0.00)$ & 6.92 \\
\hline December & $03.0(3.0)$ & $20.9(20.2)$ & $11.9(11.6)$ & $0.00(15.00)$ & 8.47 \\
\hline January & $01.0(1.0)$ & $17.2(17.7)$ & $9.1(09.4)$ & $58.80(4.00)$ & 10.77 \\
\hline February & $02.4(5.10)$ & $17.5(19.1)$ & $09.95(12.1)$ & $22.60(20.70)$ & 15.46 \\
\hline March & $07.9(10.35)$ & $24.9(24.77)$ & $16.4(17.56)$ & $9.80(11.41)$ & 6.99 \\
\hline April & $13.6(13.80)$ & $30.2(29.6)$ & $21.9(21.7)$ & $51.2(14.00)$ & 11.30 \\
\hline \multicolumn{7}{|l}{ Total rainfall during the growing season } & $184.3(75.26)$ & 64.49 \\
\hline
\end{tabular}

without parenthesis = for crop season 2011-12

with parenthesis $\quad=$ for crop season 2012-13

$* 10$ years $\quad=2002-03$ to $2012-13$ 


\section{Results and Discussion \\ Emergence $\mathbf{~ m}^{-2}$}

Data regarding seedling emergence $\left(\mathrm{m}^{-2}\right)$ of canola are given in Table 2. Statistical analysis of the two years average data revealed that emergence $\left(\mathrm{m}^{-2}\right)$ was not significantly $(\mathrm{p}<0.05)$ affected by green manuring crop (C), green manuring (GM), age at green manuring (AGM), nitrogen levels $(\mathrm{N})$ and all the possible interactions which could be due to the fact that at the time of emergence seed indigenous food reserves are metabolized and used thus germination is usually is not affected by soil nutrients status.

\section{Leaf area plant ${ }^{-1}$}

Leaf area plant ${ }^{-1}\left(\mathrm{~cm}^{2}\right)$ of canola was significantly affected by C, GM, AGM and $\mathrm{N}$ levels. Interactions between AGM x C, C $x \mathrm{GM} \times \mathrm{N}$, and $\mathrm{C} \times \mathrm{AGM} \times \mathrm{N}$ were also found significant for leaf area plant ${ }^{-1}$. Guar sown as preceding green manuring crop showed maximum leaf area plant ${ }^{-1}$ (1777 $\mathrm{cm}^{2}$ ) of canola as compared to preceding millet sown plots $\left(1456 \mathrm{~cm}^{2}\right)$ which could be due to the amount and availability of $\mathrm{N}$ due to guar as leguminous crop. Mean values for green manuring showed that plots where whole plants were incorporated had broader leaves $\left(1644 \mathrm{~cm}^{2}\right)$ as compare to plots where only stubbles were incorporated $\left(1593 \mathrm{~cm}^{2}\right)$. Green manuring at 70 days after sowing (DAS) had higher leaf area plant ${ }^{-1}(1768$ cm2) while minimum leaf area plant ${ }^{-1}$ (1483 $\mathrm{cm} 2$ ) was recorded with green manuring at 40 DAS. Leaf area plant ${ }^{-1}$ increased with the increase in $\mathrm{N}$ level and the highest leaf area plant $^{-1}\left(1744 \mathrm{~cm}^{2}\right)$ was recorded with $100 \mathrm{~kg}$ $\mathrm{N} \mathrm{ha}^{-1}$, while lowest leaf area plant ${ }^{-1}$ (1507 $\mathrm{cm} 2$ ) of canola was recorded in control plots $\left(0 \mathrm{~kg} \mathrm{~N} \mathrm{ha}{ }^{-1}\right)$. These results are in conformity with the reported by [21] who reported an increase in leaf area in canola with the increase in nitrogen level.
Interaction between AGM x C (Fig. 1) showed that both the crops green mannured at 70 DAS has increased leaf area plant $^{-1}$. Decline in leaf area plant ${ }^{-1}$ was observed with delay in incorporation (100 DAS). In case of green manuring crop species, guar performed better when incorporated at the age of 70 DAS when compared to millet for boosting leaf area plant ${ }^{-1}$. The interaction of $\mathrm{C} \times \mathrm{GM} \times \mathrm{N}$ (Fig. 2) revealed that the increase in $\mathrm{N}$ level irrespective of crop species or green manuring (incorporation or removal) increased leaf area plant $^{-1}$. Leaf area plant $^{-1}$ response to guar as a green manuring crop was more than millet. Increase in the yield, stem length and leaf surface area in spinach with the increase in the fertilizer $\mathrm{N}$ level is reported by [22]. Green manuring of whole plants as a whole was not beneficial in terms of increased leaf area plant-1 when compared with stubbles only. The interaction of C x AGM x N (Fig. 3 ) indicated that with the increase in $\mathrm{N}$ level leaf area plant-1 increased in both the crops irrespective of its age at green manuring. Leaf area plant $^{-1}$ responded well to incorporation at the age of 70 DAS in both the crops. Green manuring of guar was better than millet even without addition of $\mathrm{N}$ to guar. These results are supported by [23] who reported increase in leaf area with the increase in $\mathrm{N}$ level up $120 \mathrm{~kg} \mathrm{ha}^{-1}$ in their study.

\section{Days to maturity}

Days to maturity of canola was significantly $(\mathrm{p}<0.05)$ affected by GM and $\mathrm{N}$ levels while all the possible interactions were found nonsignificant. Perusal of the data indicated that plots with whole plants incorporation significantly delayed maturity $(179 \mathrm{~d})$ as compared to stubbles incorporated plots $\left(\begin{array}{ll}178 & \text { d}\end{array}\right)$ Nitrogen application had significantly affected maturity. Plots with $100 \mathrm{~kg} \mathrm{~N} \mathrm{ha}^{-1}$ supply took more days (179 d) to maturity as compared with no $\mathrm{N}$ supply, 
however it was at par with $75 \mathrm{~kg} \mathrm{~N} \mathrm{ha}^{-1}$ application. The probable reason for this might be the additional $\mathrm{N}$ availability from guar being a leguminous which resulted delay in maturity. These results are in line with the findings of [24-26] who reported delay in maturity with the increase in nitrogen level. The 2nd year (2012-13) of the experiment took significantly more days to flowering which is probably due to carry over and accumulative effect of nutrients release from the residues decomposition after a year time.

\section{Plant height}

Data regarding plant height $(\mathrm{cm})$ of canola revealed that $\mathrm{C}, \mathrm{AGM}$ and $\mathrm{N}$ levels $(\mathrm{N})$ and the interaction between $\mathrm{C} \times \mathrm{AGM}$ had significantly affected plant height $(\mathrm{cm})$ of canola Table 1. Guar as preceding green manuring crop produced significantly taller plants $(153 \mathrm{~cm})$ as compare with millet sown plots $(142 \mathrm{~cm})$. Green manuring at 100 DAS had produced dwarf plants with height of $143 \mathrm{~cm}$ as compared with green manuring at 40 DAS or 70 DAS $(152 \mathrm{~cm})$. Increase in plant height when guar was sown as a preceding green manuring crop could be due to the sufficient availability of nitrogen in those plots when compared to millet sown plots. These results are in line with those reported by [27] who stated that legumes have a greater restorative effect of soil $\mathrm{N}$ than grasses and highlighted a beneficial role of legumes for the successding crops. Significant increase in plant height with the increase in $\mathrm{N}$ levels from 0 to $75 \mathrm{~kg} \mathrm{ha}^{-1}$ was recorded. Plant height did not significantly increased at the highest level of $\mathrm{N}(100 \mathrm{~kg}$ ha-1). These findings are in agreement with the findings of [28-34] who reported that $\mathrm{N}$ fertilizers have a stimulating and direct impact on vegetative growth and development of plants. The increase in growth characters with the increase in nitrogen level might be due to the role of nitrogen that is reflected in the form of taller plants.

The interaction between $\mathrm{C} \times \mathrm{AGM}$ (Fig. 4) showed that initially plant height of canola for both the green manuring crops when incorporated at 40 DAS was almost similar. In case of guar increase in plant height of canola was recorded at 70 DAS incorporation while millet showed different trend where plant height decreased with the age of green manuring. Plant height in both the crops decreased with the age of green manuring. The probable reason might be the fact that as plant matures its protein and other water soluble contents decreases steadily, whereas the amount of hemicelluloses, cellulose and lignin increases. Consequently, the residues of immature plants generally decompose readily than those of older plants [35]. These findings are confirmed by $[9,36,37]$ who recorded an increase in soil organic matter by $\mathrm{N}$ inputs from both fertilizer $\mathrm{N}$, by retention of residues and N2 fixation by legumes. The organic matter content was increased after preceding or succeeding legume crops than after proceeding or succeeding cereal crops that might have resulted in increase in plant height. Second year of the experiment produced taller plants which might be the carry over and accumulative effects of nutrients release from legumes decomposition after a year time.

\section{Biological yield}

Biological yield ( $\mathrm{t} \mathrm{ha}^{-1}$ ) of canola was significantly affected by C, GM, AGM and $\mathrm{N}$ levels (Table 2). The interactions between $\mathrm{C} \times \mathrm{GM}$ and $\mathrm{C} \times \mathrm{AGM} \times \mathrm{N}$ were also found significant for biological yield. Mean values indicated that guar sown as green manuring preceding crop produced maximum biological yield (10.564 $\left.\mathrm{t} \mathrm{ha}^{-1}\right)$ of canola as compare to millet sown plots $\left(9.418 \mathrm{t} \mathrm{ha}^{-1}\right)$. These results are in line with those of [38] 
who reported that legumes crop residues have higher nitrogen contents having narrow $\mathrm{C}$ : $\mathrm{N}$ ratios. This lower $\mathrm{C}: \mathrm{N}$ ratio helps in faster decomposition than the cereals residues. Data further suggested that whole plants incorporated plots had produced maximum biological yield $\left(10.179 \mathrm{t} \mathrm{ha}^{-1}\right)$ of canola as compare to plots where only stubbles were incorporated (9.818 t ha-1). These results are in line with those reported by [39] who stated that green manuring of crop into the soil resulted in the improvement of soil physical, chemical and biological properties which lead to the increase in canola yield. Green manuring at 40 DAS had produced maximum biological yield (10.481 t ha-1) followed by 70 DAS (10.369 $\left.\mathrm{t} \mathrm{ha}^{-1}\right)$ while the lowest biological yield (9.147 $\mathrm{t} \mathrm{ha}^{-1}$ ) was recorded in plots green mannured at 100 DAS. Biological yield increased with the increase in $\mathrm{N}$ levels as maximum biological yield (11.2 $\left.\mathrm{t} \mathrm{ha}^{-1}\right)$ was recorded at $100 \mathrm{~kg} \mathrm{~N}$ ha-1 while minimum biological yield of $8.287 \mathrm{t} \mathrm{ha}^{-1}$ was recorded in control plots. The possible reason for the increase in biological yield with the increase level of $\mathrm{N}$ is that $\mathrm{N}$ increases the vegetative growth resulting in more photosynthates, which increase the growth and development of the crop and thus resulted in the increase in biological yield. Other reason for this might be that crop growth rate and duration of the growth both indicate the potential for improvement in the yield. It is perhaps related to accelerating the photosynthesis activity and the activities of photosynthesizing tissues during the growth period [40]. These results are in line with the findings of $[41,13,42$,
24] who reported similar trend of increasing biological yield with the increase in $\mathrm{N}$ rates. Significantly higher biological yield was recorded in the second year of the experiment as compared with the first year. The probable reason for this could be residual $\mathrm{N}$ during the second year of the experiment.

The interaction between C x GM (Fig. 5) showed that whole plants incorporation in guar sown plots enhanced biological yield of canola. Millet sown as a preceding green manuring crop had lower biological yield as compared with guar. The interaction for $\mathrm{C} \mathrm{x}$ AGM $x$ N (Fig. 6) suggested a linear increase in biological yield of canola with the increase in $\mathrm{N}$ levels in both guar and millet sown plots. Green manuring at 40 DAS leveled off after $75 \mathrm{~kg} \mathrm{~N} \mathrm{ha}^{-1}$ in case of millet while it increased up to $100 \mathrm{~kg} \mathrm{~N}$ ha-1 when guar was incorporated at 40 DAS. Significantly higher biological yield of $11.875 \mathrm{t}$ ha- 1 was recorded in 2 nd year as compared with 1 st year $\left(8.1 \mathrm{t} \mathrm{ha}^{-1}\right)$ of the experiment. Similar results were reported by [38] who stated that legumes crop residues have higher nitrogen contents resulting in faster decomposition than the cereals residues resulting in more availability of $\mathrm{N}$ to the plant that increased the yield and yield components of winter oilseed. Further, [39, 43] found that crop residues incorporation into the soil acts as a source of mineral elements that can sustain plant growth and boost the activities of soil microorganisms, provide an ideal condition for canola growth resulting not only yield increase but also reduces the $\mathrm{N}$ requirement of canola. 
Table 2. Emergence $\mathrm{m}^{2}$, Leaf area plant ${ }^{-1}$, days to maturity, plant height $(\mathrm{cm})$ and biological yield of canola as influenced by green manuring crops, its incorporation and age at green manuring under varying nitrogen levels.

\begin{tabular}{|c|c|c|c|c|c|}
\hline & $\begin{array}{l}\text { Emergence } \\
\left(\mathbf{m}^{-2}\right)\end{array}$ & $\begin{array}{l}\text { Leaf area } \\
\text { plant }^{-1}\end{array}$ & $\begin{array}{l}\text { Days to } \\
\text { maturity }\end{array}$ & $\begin{array}{l}\begin{array}{l}\text { Plant } \\
\text { height } \\
\text { (cm) }\end{array} \\
\end{array}$ & $\begin{array}{l}\text { Biological } \\
\text { yield } \\
\left(\mathrm{t} \mathrm{ha}^{-1}\right)\end{array}$ \\
\hline \multicolumn{6}{|c|}{ Green manuring Crops $(\mathrm{C})$} \\
\hline Millet & 93 & $1456 \mathrm{~b}$ & 178 & $142 \mathrm{~b}$ & $9.418 \mathrm{~b}$ \\
\hline Guar & 98 & $1777 \mathrm{a}$ & 179 & $153 \mathrm{a}$ & $10.564 \mathrm{a}$ \\
\hline Significance level & $\mathrm{ns}$ & $* *$ & ns & $* *$ & $* *$ \\
\hline \multicolumn{6}{|c|}{ Green Manuring (GM) } \\
\hline whole plants & 94 & $1644 \mathrm{a}$ & 179 a & 149 & $10.179 \mathrm{a}$ \\
\hline stubbles only & 97 & $1593 \mathrm{~b}$ & $178 \mathrm{~b}$ & 146 & $9.818 \mathrm{~b}$ \\
\hline Significance level & ns & *** & $* *$ & ns & $* *$ \\
\hline \multicolumn{6}{|c|}{ Age at green manuring AGM (Days) } \\
\hline 40 & 94 & $1483 \mathrm{c}$ & 179 & $148 \mathrm{a}$ & $10.481 \mathrm{a}$ \\
\hline 70 & 99 & $1768 \mathrm{a}$ & 179 & $152 \mathrm{a}$ & $10.369 \mathrm{a}$ \\
\hline 100 & 93 & $1605 \mathrm{~b}$ & 178 & $143 \mathrm{~b}$ & $9.147 \mathrm{~b}$ \\
\hline $\operatorname{LSD}_{(0.05)}$ & ns & 74 & $\mathrm{~ns}$ & 4.9 & 0.572 \\
\hline \multicolumn{6}{|c|}{ Nitrogen levels $(\mathrm{N}) \mathrm{kg} \mathrm{ha}^{-1}$} \\
\hline 0 & 94 & $1507 \mathrm{c}$ & $178 \mathrm{~b}$ & $141 \mathrm{~b}$ & $8.287 \mathrm{c}$ \\
\hline 75 & 96 & $1606 \mathrm{~b}$ & $179 \mathrm{ab}$ & $151 \mathrm{a}$ & $10.463 \mathrm{~b}$ \\
\hline 100 & 96 & $1744 \mathrm{a}$ & $179 \mathrm{a}$ & $151 \mathrm{a}$ & $11.246 \mathrm{a}$ \\
\hline $\operatorname{LSD}_{(0.05)}$ & ns & 32 & 0.6 & 3.8 & 0.343 \\
\hline \multicolumn{6}{|l|}{ Year Means } \\
\hline $2011-12$ & 89 & 1539 & $173 b$ & $134 \mathrm{~b}$ & $8.123 b$ \\
\hline $2012-13$ & 101 & 1699 & $184 \mathrm{a}$ & $161 \mathrm{a}$ & $11.875 \mathrm{a}$ \\
\hline \multicolumn{6}{|l|}{ Interactions } \\
\hline $\mathrm{AGM} \times \mathrm{C}$ & ns & ** Fig. 3 & ns & $* *$ Fig. 6 & ns \\
\hline $\mathrm{GM} \times \mathrm{N}$ & ns & $\mathrm{ns}$ & ns & ns & ns \\
\hline AGM $\times$ GM & ns & ns & ns & ns & ns \\
\hline AGM $\times \mathrm{N}$ & ns & ns & ns & ns & ns \\
\hline AGM $x$ GM $\times$ N & ns & ns & ns & ns & ns \\
\hline $\mathrm{C} \times \mathrm{GM}$ & ns & ns & ns & ns & ** Fig. 7 \\
\hline $\mathrm{C} \times \mathrm{N}$ & $\mathrm{ns}$ & ns & ns & ns & ns \\
\hline $\mathrm{C} \times \mathrm{GM} \times \mathrm{N}$ & ns & ** Fig. 4 & ns & ns & ns \\
\hline AGM x C x GM & ns & $\mathrm{ns}$ & ns & ns & ns \\
\hline $\mathrm{C} \times \mathrm{AGM} \times \mathrm{N}$ & $\mathrm{ns}$ & $*$ Fig 5 & ns & ns & ** Fig. 8 \\
\hline AGMxCxGMxN & $\mathrm{ns}$ & ns & $\mathrm{ns}$ & ns & ns \\
\hline
\end{tabular}

Means of the same category followed by different latter are significantly different from one another at $5 \%$ and $1 \%$ level of probability. Where $* * *=$ Significant at 5 and $1 \%$ level of probability, respectively. ns $=$ non-significant 


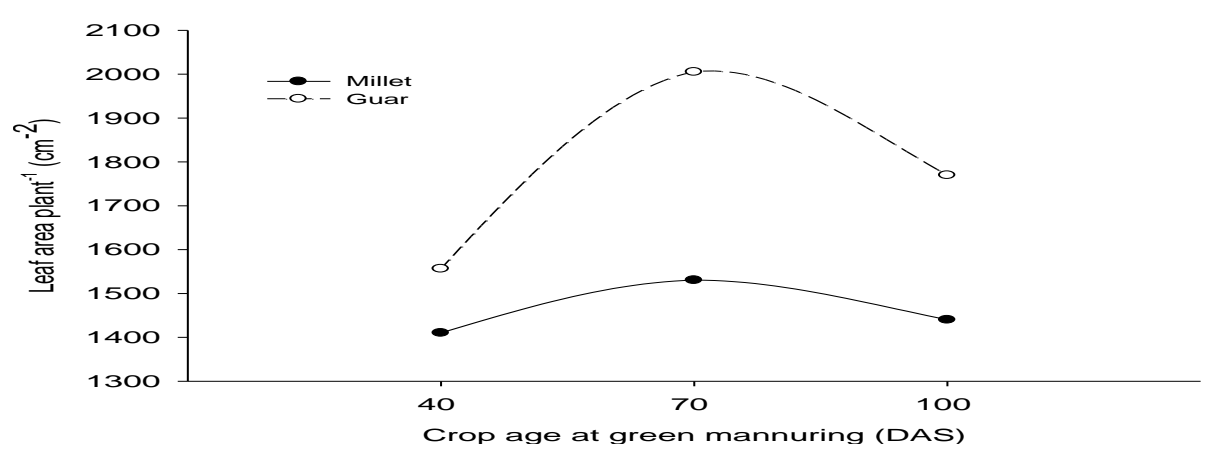

Fig. 1. Interaction between $\mathrm{AGM} \times \mathrm{C}$ for leaf area $\left(\mathrm{cm}^{2}\right)$ of canola

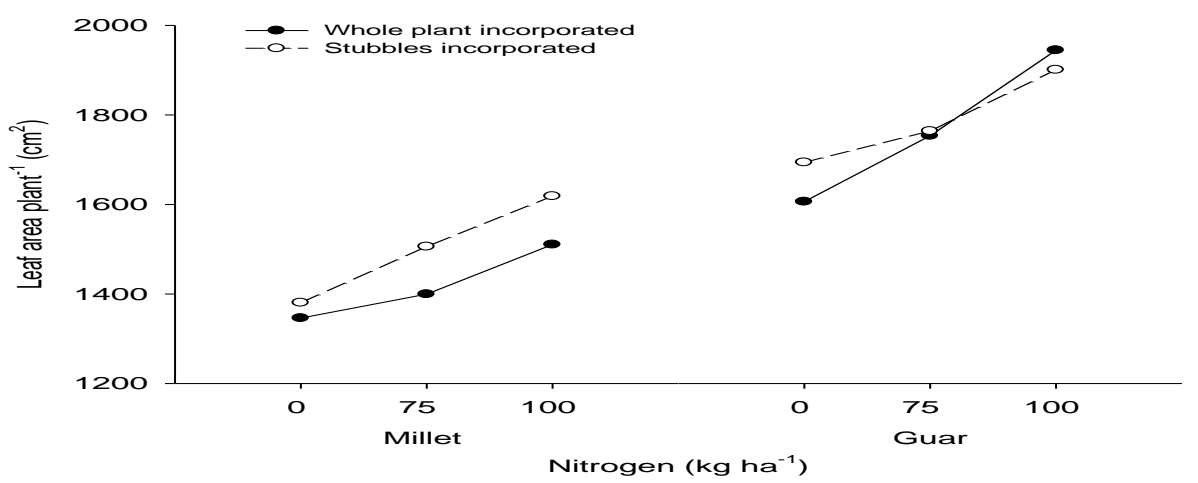

Fig. 2. Interaction between $\mathrm{C} x \mathrm{GM} \times \mathrm{N}$ for leaf area $\left(\mathrm{cm}^{2}\right)$ of canola

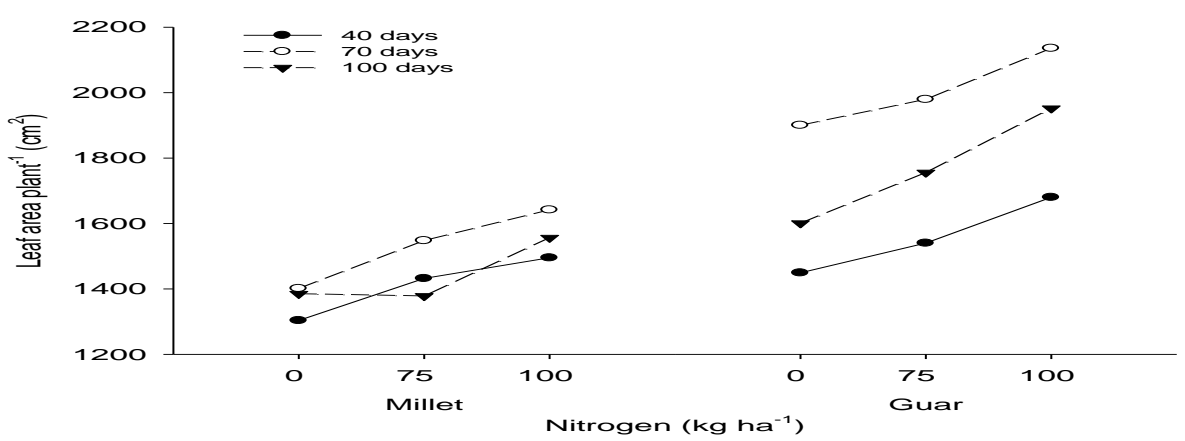

Fig. 3. Interaction between $\mathrm{C} \times \mathrm{AGM} \times \mathrm{N}$ for leaf area $\left(\mathrm{cm}^{2}\right)$ of canola 
Ali et al.

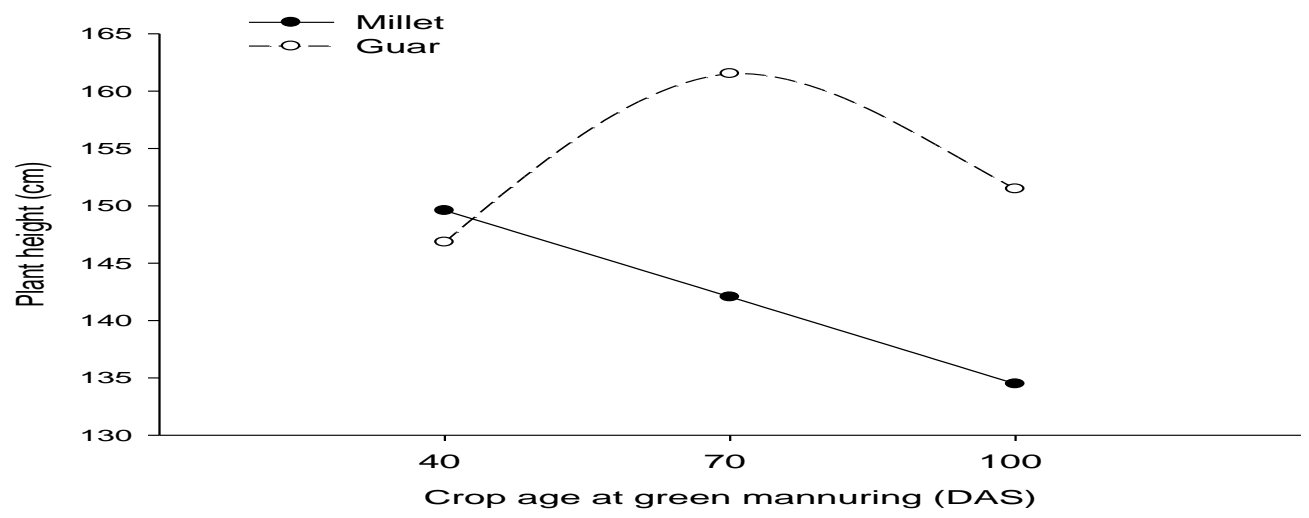

Fig. 4. Interaction between AGM $x \mathrm{C}$ for plant height $(\mathrm{cm})$ of canola

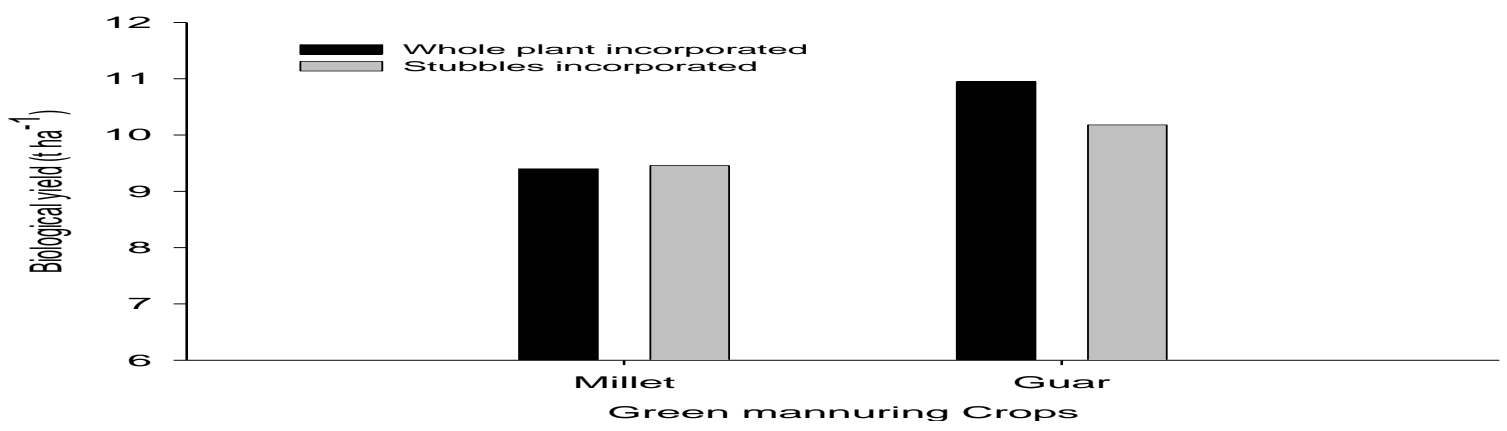

Fig. 5. Interaction between $\mathrm{C} x \mathrm{GM}$ for biological yield $\left(\mathrm{t} \mathrm{ha}^{-1}\right)$ of canola

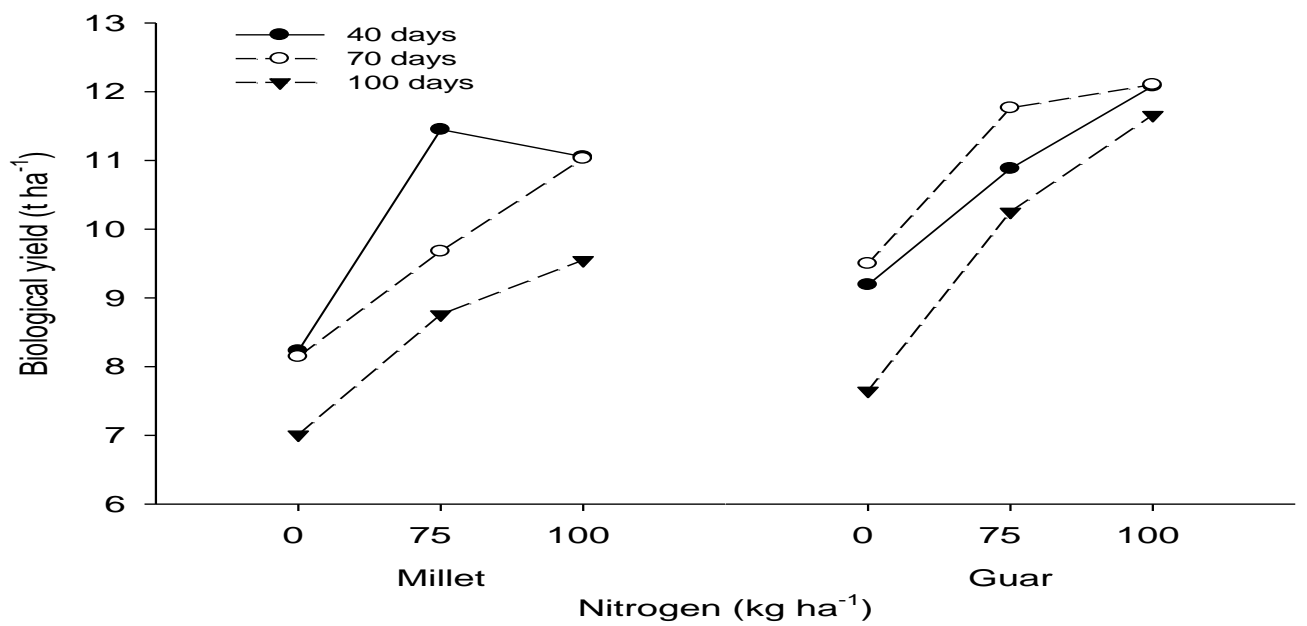

Fig. 6. Interaction between $\mathrm{C} x \mathrm{AGM} \times \mathrm{N}$ for biological yield $\left(\mathrm{t} \mathrm{ha}^{-1}\right)$ of canola 


\section{References}

1. Ahmadi M \& Bahrani MJ (2009). Yield and yield components of rapeseed as influenced by water stress at different growth stages and nitrogen levels. American-Eurasian J Agric \& Environ Sci 5(6): 755-761.

2. FAO (2012-13). Statistical Yearbook. FAO Statistics Division, Rome, Italy.

3. Canola Council of Canada. 2005. The growers manual (online). Available at Canola Council of Canada, Winnipeg, MB, Canada.

4. Cheema MA, Malik MA, Hussain A, Shah SH \& Basra SMA (2001). Effects of time and rate of nitrogen and phosphorus application on the growth and the seed and oil yields of canola (Brassica napus L.). J Agron and Crop Sci 186(2):103-110.

5. GOP (2012-13). Economic survey report. 2012-13. Govt of Pak. Finance Division, Islamabad.

6. MINFA (2011-12). Agriculture statistic of Pakistan. Ministry for Food Agriculture and Livestock, Economic wing, Government of Pakistan, Islamabad.

7. Reddy SR (2004). Rapeseed and mustard. 423-437. Agronomy of Field crops. Kalyani Publishers. India.

8. Rashid A (1996). Secondary and micronutrients. P. 341-372. In A. Rashid, Qazi Suleman Memon, Elena Bashir and Robyn Band (eds) Soil Science. National Book Foundation: Islamabad.

9. Shah Z, Shah SH, Peoples MB, Schwenke GD \& Herridge DF (2003). Crop residue and fertilizer $\mathrm{N}$ effects on nitrogen fixation and yields of legume-cereal rotations and soil organic fertility. Field Crops Res 83(1): 1-11.
10. Habtegebrial K, Singh BR \& Haile M (2007). Impact of tillage and nitrogen fertilization on yield, nitrogen use efficiency of tef (Eragrostis tef (Zucc.) Trotter) and soil properties. Soil and Tillage Res 94(1): 55-63.

11. Narits L (2010). Effect of nitrogen rate and application time to yield and quality of winter oilseed rape (Brassica napus L. var. oleifera subvar. biennis). Agro Res 8: 671686.

12. Rathke GW, Christen O \& Diepenbrock W (2005). Effects of nitrogen source and rate on productivity and quality of winter oilseed rape (Brassica napus L.) grown in different crop rotations. Field crops Res 94(2):103-113.

13. Malidarreh A (2010). Effects of nitrogen rates and splitting on oil content and seed yield of canola (Brassica. napus L.). American-Eurasian J Agric and Environ Sci 8(2): 161-166.

14. Khan A, Jan MT, Marwat KB \& Arif M (2009). Organic and inorganic nitrogen treatments effects on plant and yield attributes of maize in a different tillage systems. Pak J Bot 41(1): 99-108.

15. Eagle AJ, Bird JA, Hill JE, Horwath WR \& van Kessel C (2001). Nitrogen dynamics and fertilizer use efficiency in rice following straw incorporation and winter flooding. $J$ Agron 93(6): 1346-1354.

16. Ojiem JO, De Ridder N, Vanlauwe B \& Giller KE (2006). Socio-ecological niche: a conceptual framework for integration of legumes in smallholder farming systems. Intern J Agric Sustain 4(1): 79-93.

17. Campiglia E, Caporali F, Barberi R \& Mancinelli R (1999). Influence of 2, 
3, 4 and 5 year stands of alfalfa on winter wheat yield. In Proc. Int. Workshop 'Designing and Testing Crop Rotations for Organic Farming'. DARCOF, Tjele, DK. pp: 165-171.

18. Kirkegaard J, Christen O, Krupinsky J \& Layzell D (2008). Break crop benefits in temperate wheat production. Field Crops Res 107: 185-195.

19. Timsina J \& Connor DJ (2001). Productivity and management of rice-wheat cropping systems: issues and challenges. Field crops Res 69(2): 93-132.

20. Steel RGD \& Torrie JH (1980). Principles and Procedures of Statistics: A Biometrical Approach. 2nd ed., McGraw Hill Book Co., New York.

21. Bybordi A \& Ebrahimian E (2013). Growth, yield and quality components of canola fertilized with urea and zeolite. Soil Sci Plant Anal 44(19): 2896-2915.

22. Gülser F (2005). Effects of ammonium sulphate and urea on $\mathrm{NO} 3$ and NO2 accumulation, nutrient contents and yield criteria in spinach. Scientia Horti 106(3): 330-340.

23. Ngezimana W \& Agenbag GA (2013). Effects of nitrogen and sulfur on Canola (Brassica napus L.) vegetative and reproductive growth under controlled conditions. African J Agric Res 8(39): 4887-4894.

24. Brandt SA, Malhi SS, Ulrich D, Lafond GP, Kutcher HR \& Johnston AM (2007). Seeding rate, fertilizer level and disease management effects on hybrid versus open pollinated canola (Brassica napus L.). Canadian $J$ Plant Sci 87(2): 255-266.
25. Ozer H (2003). Sowing date and nitrogen rate effects on growth, yield and yield components of two summer rapeseed cultivars. Europ $J$ Agron 9(3):453-463.

26. Kamkar B, Daneshmand AR, Ghooshchi F, Shiranirad AH \& Safahani Langeroudi AR (2011). The effects of irrigation regimes and nitrogen rates on some agronomic traits of canola under a semiarid environment. Agric Water Management 98(6):1005-1012.

27. Lupwayi NZ, Clayton GW, O'Donovan JT, Harker KN, Turkington TK \& Soon YK (2006). Nitrogen release during decomposition of crop residues under conventional and zero tillage. Can J Soil Sci 86 (1): 11-19.

28. Khan H, Khan MA, Hussain I, Malik AS \& Baloch MS (2000). Effect of nitrogen and phosphorus on growth and yield of Brassica juncea L. Pak J Bio Sci 3(8): 1231-1233.

29. Al-Barrak KM (2006). Irrigation interval and nitrogen level effects on growth and yield of canola (Brassica napus L.). Sci J King Faisal Uni 7(1):87102.

30. Malhi SS \& Gill KS (2006). Placement, rate and source of $\mathrm{N}$, seedrow opener and seeding depth effects on canola production. Can J Plant Sci 84: 719-729.

31. Rashid R, Karim MF \& Hasanuzzaman M (2007). Response of rapeseed (Brassica campestris L.) to different nitrogen doses and number of weeding. Mid East J Sci Res 2(3-4): 146-150.

32. Karamzadeh A, Mobasser HR, Ramee V \& Ghanbari-Malidarreh A (2010). Effects of nitrogen and seed rates on yield and oil content of Canola 
(Brassica napus L.). Am-Euras J Agric Environ Sci 8: 715-721.

33. Mansoori I (2012). Response of canola to nitrogen and sulfur fertilizers. Intern J Agric \& Crop Sci 4(1:28-33.

34. El-Nakhlawy FS \& Bakhashwain AA (2009). Performance of Canola (Brassica napas L.), seed yield, yield Components and seed quality under the Effects of four genotypes and nitrogen fertilizer rates. Environ \& Arid Land Agric Sci 20(2): 33-47.

35. Kumar K \& Goh KM (1999). Crop residues and management practices: Effects on soil quality, soil nitrogen dynamics, crop yield, and nitrogen recovery. Adv Agron 68:197-319.

36. Shafi M, Bakht J, Jan MT \& Shah Z (2007). Soil C and N dynamics and maize yield as affected by cropping system and residue management in North Western Pakistan. Soil and Tillage Res 94: 520-529.

37. Bakht J, Shafi M, Jan MT \& Shah Z. (2009). Influence of crop residue management, cropping system and $\mathrm{N}$ fertilizer on soil $\mathrm{N}$ and $\mathrm{C}$ dynamics and sustainable wheat (Triticum aestivum L.) production. Soil and Tillage Res 104(2): 233-240.

38. Adjei-Nsiah, S, Kuyper TW, Leeuwis C, Abekoe MK, Cobbinah J, SakyiDawson O \& Giller KE (2008). Farmers' agronomic and social evaluation of productivity, yield and
N2-fixation in different cowpea varieties and their subsequent residual $\mathrm{N}$ effects on a succeeding maize crop. Nutrient Cycling in Agro-ecosystems 80(3): 199-209.

39. Hejazi A, Bahrani MJ \& Kazemeini SA (2010). Yield and yield components of irrigated Rapeseed- Wheat rotation as influences by crop residues and nitrogen levels in a reduced tillage method. AmericanEurasian J Agric \& Environ Sci 8(5): 502-507.

40. Diepenbrock W (2000). Yield analysis of winter oilseed rape (Brassica napus L.): A Review Field Crops Res 67(1): 35-49.

41. Taheri E, Soleymani A \& Javanmard HR (2012). The effect of different nitrogen levels on oil yield and harvest index of two spring rapeseed cultivars in Isfahan region. Intl $J$ Agric Crop Sci 4(20), 1496-1498.

42. Kardgar V, Delkhosh B, Noormohammadi G \& Shiranirad AH (2010). Effects of nitrogen and plant density on yield of field mustard (Brassica campestris L.). Plant Physio 2(4): 157-164.

43. Aynehband A, Taheri M \& Nabati DA (2010). Effect of residues management and $\mathrm{N}$-splitting methods on yield and biological and chemical characters of canola ecosystem. $J$ Food \& Environ 8(2):317-324. 